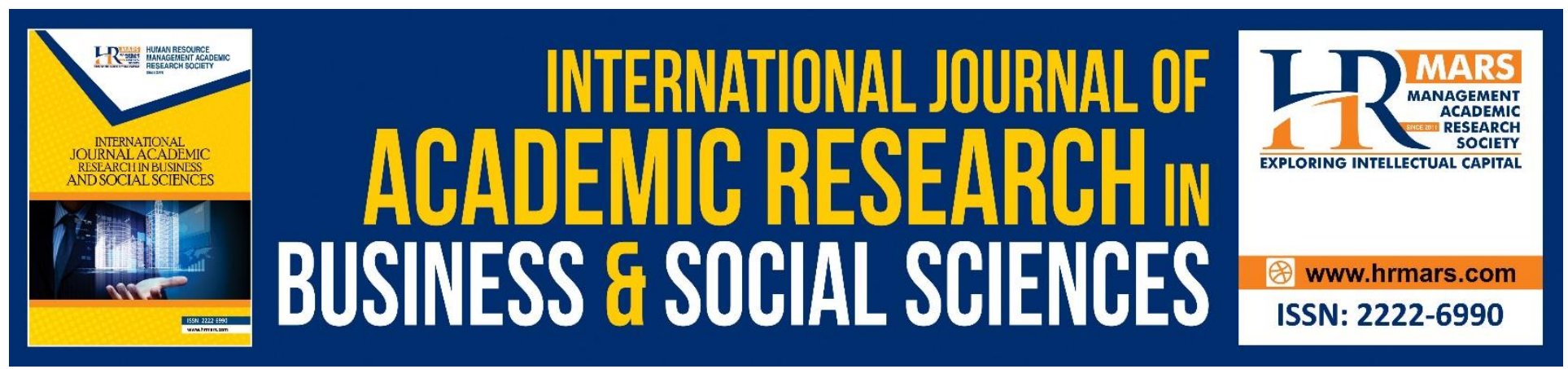

\title{
Empowering Rural Women's Involvement in Income Generating Activities Through BRAC Microfinance Institution in Sylhet District, Bangladesh
}

Aysha Akter, Nobaya Ahmad

To Link this Article: http://dx.doi.org/10.6007/IJARBSS/v10-i16/8298

DOI:10.6007/IJARBSS/v10-i16/8298

Received: 07 October 2020, Revised: 25 October 2020, Accepted: 06 November 2020

Published Online: 23 November 2020

In-Text Citation: (Akter \& Ahmad, 2020)

To Cite this Article: Akter, A., \& Ahmad, N. (2020). Empowering Rural Women's Involvement in Income Generating Activities Through BRAC Microfinance Institution in Sylhet District, Bangladesh. International Journal of Academic Research in Business and Social Sciences, 10(11), 146-161.

Copyright: (c) 2020 The Author(s)

Published by Human Resource Management Academic Research Society (www.hrmars.com)

This article is published under the Creative Commons Attribution (CC BY 4.0) license. Anyone may reproduce, distribute, translate and create derivative works of this article (for both commercial and non-commercial purposes), subject to full attribution to the original publication and authors. The full terms of this license may be seen at: http://creativecommons.org/licences/by/4.0/legalcode

Special Issue: Youth and Community Wellbeing: Issues, Challenges and Opportunities for Empowerment V2, 2020, Pg. 146 - 161 http://hrmars.com/index.php/pages/detail/IJARBSS JOURNAL HOMEPAGE

Full Terms \& Conditions of access and use can be found at http://hrmars.com/index.php/pages/detail/publication-ethics 


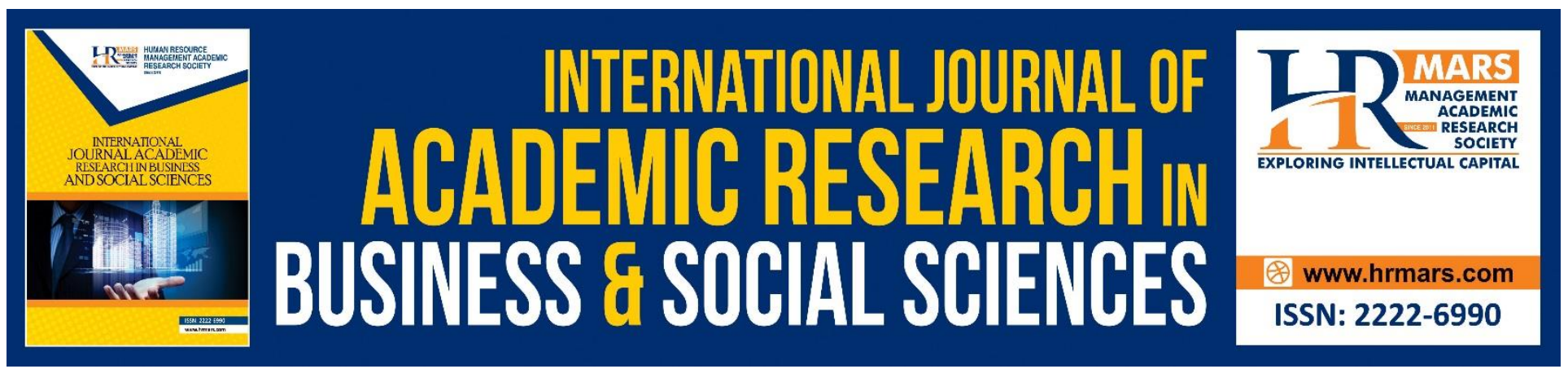

\title{
Empowering Rural Women's Involvement in Income Generating Activities Through BRAC Microfinance Institution in Sylhet District, Bangladesh
}

\author{
Aysha Akter, Nobaya Ahmad \\ Institute for Social Science Studies, Universiti Putra Malaysia, 43400 Serdang, Selangor, Malaysia \\ Department of Social and Development Sciences, Faculty of Human Ecology, Universiti Putra \\ Malaysia, 43400 Serdang, Selangor, Malaysia \\ Email: aysha.sau@gmail.com, nobaya@upm.edu.my
}

\begin{abstract}
This article presented the findings on the role of microcredit financial assistance, specifically from Bangladesh Rural Advancement Committee (BRAC) Micro-finance institution to assist rural women in Sylhet District, Bangladesh involved in income generating activities. The impact on their socioeconomic empowerment, the constraints of rural women in having access to loan service from microfinance institutions and loan repayment process will be discussed. The target population of the study was those women who had availed microcredit facilities from some microcredit providing institutions or organizations in the study area. Survey method was used as a technique for data collection. The results of the analysis indicate that participation of rural women in micro-finance assisted income generating activities contributes towards socioeconomic empowerment. It also showed that most of the rural women who availed the facility of microcredit finally became empowered through acquiring the confidence level, business skills, decision making power, and self-esteem. The findings also showed that microcredit has significant impact on the up lift of socio-economic empowerment of the women's in Sylhet district. However, constraints of rural women in accessing loan and loan repayment process should be properly addressed by the stakeholders to improve the contribution of micro- finance institutions for achieving sustainable development goal. Hence, accessing microcredit has been able to empower women financially and it is suggested that microcredit loan be made accessible to poor women who are keen to uplift the family's economic wellbeing.

Keywords: Rural Women, Micro-Credit, Empowerment, Income Generating Activities, Brac MicroFinance Institution.
\end{abstract}

\section{Introduction}

The empowerment of women is an essential precondition for the alleviation of poverty and the upholding of human rights, in particular at the individual level, as it helps to build a base for social 
change (DFID, 2000). Empowerment of women is the process and the outcome of the process, by which women gain greater control over material and intellectual resources and challenge the ideology of patriarchy and the gender-based discrimination against women in all the institutions and structures of society, especially in patriarchal societies (Batliwala, 1994; Albedaiwi, 2015). Empowerment can be defined as the expansion in people's ability to make strategic life choices in a context where this ability was previously denied to them (Kabeer, 2002). Empowerment is also related to the process of internal change and to the capacity and right to make decisions (Mayoux, 1998). It consists of change, choice and power. Despite the involvement of various micro-finance institutions towards empowering women through micro-finance assisted income generating activities in Bangladesh, the status of majority of the rural women is still not encouraging in Bangladesh.

Micro-finance institutions are claimed to directly affect household income by encouraging productivity, increasing diversity of production and productivity, and maximizing the utilization of the available resources (Binswanger, 2007; Dejene, 2007; Sudan, 2007; Akintoye, 2008; Belwal et al., 2012; Fletschner \& Kenney, 2014). Women's economic empowerment is usually about increase access to financial resources, income generating activities, increase financial decision making power, savings and more economic independence (Mayoux, 2000; Ogato et al., 2009a). In other words, they were claimed to encourage the socio-economic development of the concerned families as well as societies (Mayoux, 1998; Mayoux, 2000; De Klerk, 2008; Ifelunini \& Wosowei, 2012). In many cases, when women become economically empowered, the whole family will benefit from the improved socioeconomic conditions. This is in line with the idea of Muhammad Yunus, Nobel Prize winner and founder of the Grameen Bank (GB) where microcredit was initiated and according to the Grameen Bank, microcredit is an informal banking system that "extends small loans to very poor people for self-employment projects that generate income, allowing them to care for themselves and their families" (Norwood, 2014).

Microcredit operations are not unique to developing countries. Many developing countries rely on microcredit especially as means of start-up capital for small business entrepreneurs as indicated in the websites of Grameen Bank, ACCION, FINCA (Foundation for International Community Assistance), and PRIDE (Promotion of Rural Initiatives and Development Enterprises). Bangladesh Rural Advancement Committee (BRAC), is one of the world's largest NGOs operating nationally in Bangladesh since 1972, gearing its activities towards alleviating poverty and empowering rural women. BRAC provides credit, training, and other support to rural women so that they may become involved in different types of income generating activities (IGA) and bring about meaningful changes in their lives. Information were collected to determine whether women who were involved in IGAs has been positively affected by BRAC interventions.

Micro-finance assisted income generating activities are activities that generate opportunities to generate incomes to family. Such activities may include: livestock rearing, agriculture, fishing, and post-harvest processing. They are directed towards economic focus aiming at increasing the cash income to participating families and improving their livelihoods (Hall, 1992; Mayoux, 1998; Mayoux, 2000; Omar et al., 2012; Jafree \& Ahmad, 2013; Chowdhury \& Mukhopadhaya, 2014; Wekwete, 2014).

Micro-credit is a small loan to a client involved in some kinds of entrepreneurial activities for a living, which is managed by a bank or other institution. Micro-credit has been claimed to be a solution 
to integrate marginalised women into socio-economic activities, decision-making and poverty alleviation. Micro-credit can be offered, often without collateral, to an individual or a group through lending. It has proven an effective and popular measure in the ongoing struggle against poverty, enabling those without access to lending institutions to borrow at bank rates and start small business (Microfinance Gateway, 2008). Women's participation in credit programmes leads to them contributing to family income, taking greater role in household decision-making, having greater social networks and freedom of mobility and exercising more control over their fertility (Banu et al., 2002; Basher, 2007; Webb et al., 2002; Pitt et al., 2003; Sukontamarn, 2007). Group savings and credit programmes act as the driving force to help illiterate rural women start small-scale economic activities (Acharya et al., 2007). It strengthens coping mechanisms during crisis, diversify income generation, build assets and improve the status of women (Hashemi et al., 1996; Montgomery et al., 1996; Husain et al., 1998; and Morduch, 1998).

So, access to micro-credit from BRAC is one of the very important components in empowering income for poor women in Bangladesh as well as many developing societies. There are limited studies on micro-credit's impacts and constraints of rural women for accessing loan service from microfinance institutions and loan repayment process in the study area. Hence, exploring these constraints and proposing strategic measures of empowerment are believed to have immense contribution to enable micro-finance institutions play prominent role in achieving sustainable development goals related rural women's empowerment The impacts of micro-credit also need to be examined through research, which measures how the services of a microfinance institution like BRAC contribute to the lives of its clients in such areas as employment, nutrition, education, health income and gender equity.

\section{Objectives}

The objectives of the study were:

i) to understand the role of microcredit in facilitating income generating activities of rural women;

ii) to measure the impact of micro-credit on rural women's economic empowerment;

iii) to assess constraints of rural women in accessing loan service from micro-finance institution and loan repayment process and

iv) to suggest strategic measures for empowering rural women through microfinance assisted income generating activities in the study area

\section{Methodology}

\section{Location, Population and Sample}

The study was conducted among women from two villages namely Osmanpur and Islampur of Muglabajar union of South Surma Upazila under Sylhet district of Bangladesh where 420 rural women were the residents. A representative sample of 100 housewives (around 23 percent of the population) was the sample for the present study. South Surma Upazila is not very far from Sylhet headquarters but the Upazila has all the features of rural Bangladesh. Selection of the study area was purposively as there were many micro-finance institutions working on provision of loan services for rural women in the areas to assist their income generating activities. 
Data was collected using a questionnaire. The questionnaire was carefully designed and prepared with open and closed form of questions keeping the objectives of the study in mind. The questionnaire was pre-tested earlier with 20 women. Based on the pre-test results, necessary corrections, modifications, alternation, and adjustments were made and then finalized the questionnaire accordingly. Rapport was established with the respondents through informal discussion regarding objectives of the interview. Data were collected from 10 June to 15 July 2016. The questionnaire covered aspects related to the independent variables of the study such as age, education, family size, homestead area, annual income, communication exposure, credit availability, aspiration, fatalism, problem in participating in income generating activities and problem during loan taking. The dependent variable was economic empowerment of rural women. The variables in the dependent variables were income of the respondents measured in terms of money (taka) generated annually. Both farm (vegetables, livestock and fisheries) and non-farm income sources were considered in measuring annual income of the respondents. Income of the respondents was categorised into five (e.g. very low income, low income, medium income, high income and very high income) in order to measure empowerment index.

Savings of the respondents was measured in terms of money (taka) saved annually. Different forms of savings, such as cash savings at home, savings in NGOs, savings as crops, savings in bank or rural co-operatives were considered in measuring savings of the respondents. In order to measure empowerment index. Savings of the respondents was categorised into five (e.g. very low savings, low savings, medium savings, high savings and very high savings).

Asset of the respondents was measured in terms of money (taka) value of the assets at the time of interview. Both non- productive (TV, radio, furniture and jewellery) and productive (poultry, cattle and goat) assets were taken into consideration in measuring the asset of the respondents. In order to measure empowerment index asset of the respondents was categorised into five (e.g. very low Asset, low Asset, medium Asset, high Asset and very high Asset).

Cumulative Economic Empowerment Index (CEEI) was measured by summing up savings, asset and income categories of the respondents. The CEEI score varied from 1 to 17 , where 1 indicated very low level of empowerment and 17 indicated very high level of empowerment.

The collected data were coded into numerical, compiled, tabulated and analyzed keeping the objectives of the study in mind. In order to categorize and explain the data, various statistical measures such as range, mean, percentage, standard deviation and rank were used in describing the selected variables, wherever applicable. To find out the relationships, Pearson's Product moment correlation co-efficient was used in order to explore the relationship between the concerned variables. Tables were also used in presenting data and to clarify of understanding.

\section{Results and Discussion}

\section{Selected Characteristics of the Respondents}

Data obtained regarding characteristics of the respondents showed that $(52 \%)$ of them were in the young category as compared to $14 \%$ old and $34 \%$ of the respondents were medium aged groups (Table 1). In terms of literacy, only $32 \%$ can sign forms (very basic literacy level) and in terms of level of education, $28 \%$ attended secondary school, $24 \%$ primary school, $9 \%$ illiterate and only $7 \%$ are educated above secondary level. In terms of size of family, the highest proportion (47\%) of the respondents had medium family size while $33 \%$ of the respondents had small and $20 \%$ had large 
family sized categories. The highest proportion (38\%) had medium, 30\% had small, $18 \%$ had large farm size and rest of the $14 \%$ had marginal farm size. Majority (75\%) of the respondent's rural women family had low to medium annual income compared to $25 \%$ had high income. Most of the respondents had medium (75\%) communication exposure followed by low (15\%) and high (10\%) communication, respectively. In the study area most of the respondents (70\%) had low access to credit due to repayment risk for unfavourable terms and conditions of the credit providing organizations. The respondents showed medium (80\%), level of aspiration compared to $13 \%$ high level and 7\% low level of aspiration. However, the respondents showed medium fatalism (88\%) compared to $8 \%$ of high and $4 \%$ of low fatalism. The problem in participating in income generating activities scores of all respondents ranged from 9-41, Most of the respondents had medium (59\%) problem in participation followed by low $(23 \%)$ and high (18\%) problem of participation respectively. The problem confrontation during loan taking scores of all respondents ranged from 8-42, Most of the respondents had medium (62\%) problem confrontation followed by low (20\%) and high (18\%) problem faced by the women during loan taking respectively.

Table 1. Sociodemographic background of respondents

\begin{tabular}{|c|c|c|c|c|c|c|}
\hline $\begin{array}{l}\text { Variable } \\
\text { s }\end{array}$ & $\begin{array}{l}\text { Way of } \\
\text { measurement }\end{array}$ & Observed range & $\begin{array}{l}\text { Categories } \\
\text { according to their } \\
\text { selected } \\
\text { characteristics }\end{array}$ & $\begin{array}{l}\text { Rural } \\
\text { women } \\
\text { (Number } \\
\text { or } \\
\text { percentage) } \\
\mathrm{N}=100\end{array}$ & Mean & $\begin{array}{l}\text { Standard } \\
\text { deviation }\end{array}$ \\
\hline Age & $\begin{array}{l}\text { Assigning a } \\
\text { score of } 1 \text { for } \\
\text { each year }\end{array}$ & $18-60$ & $\begin{array}{l}\text { Young(18-35) } \\
\text { Middle (36-50) } \\
\text { Old ( Above } 50 \text { ) }\end{array}$ & $\begin{array}{l}52 \\
34 \\
14\end{array}$ & 35.14 & 8.51 \\
\hline $\begin{array}{l}\text { Educatio } \\
n\end{array}$ & Score & $0-14$ & $\begin{array}{l}\text { Illiterate (0) } \\
\text { Can sign only (0.5) } \\
\text { Primary level (1-5) } \\
\text { Secondary level } \\
(6-10) \\
\text { Above Secondary } \\
\text { level (Above } 10 \\
\end{array}$ & $\begin{array}{l}9 \\
32 \\
24 \\
28 \\
7\end{array}$ & 4.32 & 3.46 \\
\hline $\begin{array}{l}\text { Family } \\
\text { size }\end{array}$ & $\begin{array}{l}\text { Assigning a } \\
\text { score of } 1 \text { for } \\
\text { each member } \\
\text { of the family }\end{array}$ & $2-10$ & $\begin{array}{l}\text { Small (up to 4) } \\
\text { Medium (5-6) } \\
\text { Large ( } 7 \text { and above) }\end{array}$ & $\begin{array}{l}33 \\
47 \\
20\end{array}$ & 5.35 & 1.55 \\
\hline $\begin{array}{l}\text { Homeste } \\
\text { ad area }\end{array}$ & Hectare & $0.17-3.21$ & $\begin{array}{lrr}\text { Marginal } & (< & 0.02) \\
\text { Small ( } & 0.02-0.99) \\
\text { Medium } & (1-2.99) \\
\text { Large } & (3.0 \quad \text { and } \\
\text { above) } & & \end{array}$ & $\begin{array}{l}14 \\
30 \\
38 \\
18\end{array}$ & 1.982 & 0.32 \\
\hline
\end{tabular}


INTERNATIONAL JOURNAL OF ACADEMIC RESEARCH IN BUSINESS AND SOCIAL SCIENCES

Vol. 10, No. 16, Youth and Community Wellbeing: Issues, Challenges and Opportunities for Empowerment V2. 2020, E-ISSN: 2222-6990 @) 2020 HRMARS

\begin{tabular}{|c|c|c|c|c|c|c|}
\hline $\begin{array}{l}\text { Annual } \\
\text { income }\end{array}$ & ‘000 Taka & $19-69$ & $\begin{array}{l}\text { Low (up to } 30) \\
\text { Medium (30-40) } \\
\text { High (41 to 80) }\end{array}$ & $\begin{array}{l}46 \\
29 \\
25\end{array}$ & 36.76 & 11.35 \\
\hline $\begin{array}{l}\text { Commun } \\
\text { ication } \\
\text { exposure }\end{array}$ & Score & $0-75$ & $\begin{array}{l}\text { Low (up to 25) } \\
\text { Medium (26-50) } \\
\text { High (above } 50)\end{array}$ & $\begin{array}{l}15 \\
75 \\
10\end{array}$ & 37.15 & 13.33 \\
\hline $\begin{array}{l}\text { Credit } \\
\text { availabili } \\
\text { ty }\end{array}$ & Rated Score & $0-60$ & $\begin{array}{l}\text { No credit receiver (0) } \\
\text { Low credit receiver } \\
\text { (up to } 15) \\
\text { Medium credit } \\
\text { receiver (16-20) } \\
\text { High credit receiver } \\
\text { (above } 20 \text { ) }\end{array}$ & $\begin{array}{l}6 \\
70 \\
9 \\
15\end{array}$ & 19.34 & 7.21 \\
\hline $\begin{array}{l}\text { Aspiratio } \\
n\end{array}$ & Score & $6-24$ & $\begin{array}{l}\text { Low (up to 10) } \\
\text { Medium (11-20) } \\
\text { High (above 20) }\end{array}$ & $\begin{array}{l}7 \\
80 \\
13\end{array}$ & 16.8 & 4.48 \\
\hline Fatalism & Score & $6-26$ & $\begin{array}{l}\text { Low (up to 12) } \\
\text { Medium (13-25) } \\
\text { High (above } 25)\end{array}$ & $\begin{array}{l}4 \\
88 \\
8\end{array}$ & 26.74 & 2.86 \\
\hline $\begin{array}{l}\text { Problem } \\
\text { In } \\
\text { participa } \\
\text { ting in } \\
\text { income } \\
\text { generati } \\
\text { ng } \\
\text { activities }\end{array}$ & Score & $9-41$ & $\begin{array}{l}\text { Low (up to } 15 \text { score) } \\
\text { Medium (16 to } 30 \\
\text { score) } \\
\text { High (above } 30 \\
\text { score) }\end{array}$ & $\begin{array}{l}23 \\
59 \\
18\end{array}$ & 21.02 & 6.231 \\
\hline $\begin{array}{l}\text { Problem } \\
\text { in } \\
\text { participa } \\
\text { tion in } \\
\text { loan } \\
\text { taking }\end{array}$ & Score & $8-42$ & $\begin{array}{l}\text { Low (up to } 12 \text { score) } \\
\text { Medium (13 to } 30 \\
\text { score) } \\
\text { High (above } 30 \text { score }\end{array}$ & $\begin{array}{l}20 \\
62 \\
18\end{array}$ & 19.07 & 5.62 \\
\hline
\end{tabular}

Source: Survey 
INTERNATIONAL JOURNAL OF ACADEMIC RESEARCH IN BUSINESS AND SOCIAL SCIENCES

Vol. 10, No. 16, Youth and Community Wellbeing: Issues, Challenges and Opportunities for Empowerment V2. 2020, E-ISSN: 2222-6990 @ 2020 HRMARS

\section{Financial Resources of Respondents}

Information in Table 2 indicated that the respondents earned an amount of 12881.45 taka on average annually from both farm and non-farm sources. Among farm sources, poultry bird was the major income earning source and earned an amount of 1762.44 taka followed by Fish Culture (765.67 taka), Goat (557.78 taka), homestead gardening (460.58tk) and Livestock (110.23 taka). Among non-farm sources, service was the major income source $(6800.00)$ followed by handicraft production (1316.67 taka) and small business ( 435.37 taka). Such economic activities enabled women to have a better access to basic needs and make important contribution to household decision making and ultimately have positive impact on women empowerment (Parvin et al., 2004).

Table 2. Income of the respondents from farm and non-farm sources

\begin{tabular}{|l|l|}
\hline Income sources & Mean value in taka (CV) \\
\hline Livestock & $110.23(567 \%)$ \\
\hline Poultry & $1762.44(262 \%)$ \\
\hline Goat & $557.78(182 \%)$ \\
\hline Homestead gardening & $460.58(152 \%)$ \\
\hline Field crop production & $672.78(222 \%)$ \\
\hline Fish Culture & $765.67(192 \%)$ \\
\hline Small business & $435.37(433 \%)$ \\
\hline Handicrafts & $1316.67(212 \%)$ \\
\hline Service & $6800.00(289 \%)$ \\
\hline Total income & 12881.45 \\
\hline
\end{tabular}

Source: Survey (Note: 1 taka is approximately USD 0.012)

It is depicted from Table 3 that the respondents deposited money in bank ( 2850.56 taka) followed by in NGOs or co-operatives (1020.00 taka), as crops (498.57 taka) and on hand (463.67 taka) and respectively. The respondents used the savings during household risks, children's education and purchasing assets.

Table 3. Savings of the respondents in different sources

\begin{tabular}{|l|l|}
\hline Savings sources & Mean value in taka (CV) \\
\hline Cash savings on hand & $463.67(137 \%)$ \\
\hline Savings as crops & $498.57(212 \%)$ \\
\hline Savings in bank & $2850.56(126 \%)$ \\
\hline Savings in NGOs or rural co-operatives & $1020.00(135 \%)$ \\
\hline Total savings & 4832.80 \\
\hline
\end{tabular}

Source: Survey (Note: 1 taka is approximately USD 0.012) 
INTERNATIONAL JOURNAL OF ACADEMIC RESEARCH IN BUSINESS AND SOCIAL SCIENCES

Vol. 10, No. 16, Youth and Community Wellbeing: Issues, Challenges and Opportunities for Empowerment V2. 2020, E-ISSN: 2222-6990 @ 2020 HRMARS

Table 4. Assets owned by the respondents

\begin{tabular}{|l|l|}
\hline Types of assets & Mean value in taka (CV) \\
\hline Poultry & $1373.32(112 \%)$ \\
\hline Goat & $722.20(219 \%)$ \\
\hline Cattle & $1563.89(104 \%)$ \\
\hline Television/radio & $1733.33(161 \%)$ \\
\hline Jewelry & $2066.67(218 \%)$ \\
\hline Furniture & $993.37(203 \%)$ \\
\hline Total assets & 8452.78 \\
\hline
\end{tabular}

Source: Survey (Note: 1 taka is approximately USD 0.012)

From Table 4, it is clear that the respondents owned both productive and non-productive assets. The mean value of productive assets was cattle 1563.89 taka, poultry 1373.32 taka, goat 722.20 taka and. regarding non-productive assets, the respondents owned jewelry (2066.67 taka), television or radio (1733.33 taka) and furniture (993.37 taka).

\section{Motivating Factors in Joining Micro-Finance Institution}

Respondents were asked to identify their main motivating factor to join micro-finance institution in their area. Peer influence was reported by more proportion of the respondents (38.2\%). $36.6 \%$, $13.1 \%$, and $12.1 \%$ of the respondents mentioned self-motivation, family influence and social capital, respectively as the main motivating factor for joining micro-finance institution (see table 5).

Table 5: Respondents' Perception on Motivating Factors in Joining Micro-Finance Institution

\begin{tabular}{|l|l|l|}
\hline Motivating Factors for joining & Frequency & Percent \\
\hline Self-motivation & 30 & 36.6 \\
\hline Family Influence & 20 & 13.1 \\
\hline Peer Influence & 35 & 38.2 \\
\hline Social Capital & 15 & 12.1 \\
\hline Total & 100 & 100.00 \\
\hline
\end{tabular}

Source: Survey

Constraints in Accessing Loan Services and Loan Repayment Process

Limited amount of loan was mentioned by more proportion of the respondents (30.7\%). Other constraints were insufficient collateral, unnecessary bureaucracy, distance from microfinance institution, and lack of awareness. (see table 6). 
INTERNATIONAL JOURNAL OF ACADEMIC RESEARCH IN BUSINESS AND SOCIAL SCIENCES

Vol. 10, No. 16, Youth and Community Wellbeing: Issues, Challenges and Opportunities for Empowerment V2. 2020, E-ISSN: 2222-6990 @ 2020 HRMARS

Table 6: Respondents' Perception on Constraints in Access Loan Service

\begin{tabular}{|l|l|l|}
\hline Constraints of an accesses & Frequency & Percent \\
\hline Insufficient collateral & 10 & 17.1 \\
\hline Unnecessary bureaucracy & 18 & 15.6 \\
\hline Limited amount of Ioan & 35 & 30.7 \\
\hline Distance to Microfinance Institution & 15 & 10.3 \\
\hline Lack of awareness & 12 & 8.7 \\
\hline No constraint & 10 & 17.6 \\
\hline Total & 100 & 100.0 \\
\hline
\end{tabular}

Source: Survey

$38.6 \%$ of the respondents mentioned mistrust between the group members as the major constraint for loan repayment process in their area. Other reasons were using loan for other purpose, lack of training, lack of follow-up, failure of the business and unwillingness to pay back the loan respectively when asked to mention the main constraint for loan repayment in the study area (see table 7).

Table 7: Respondents' Perception on Constraints in Loan Repayment Process

\begin{tabular}{|l|l|l|}
\hline Constraints for loan repayment & Frequency & Percent \\
\hline Lack of training & 20 & 12.6 \\
\hline Lack of follow-up & 14 & 8.9 \\
\hline Failure of the business & 8 & 7.0 \\
\hline Unwillingness to pay back the loan & 12 & 5.0 \\
\hline Using the loan for other purpose & 16 & 18.9 \\
\hline Mistrust between the group members & 18 & 38.6 \\
\hline No constraint & 12 & 9.0 \\
\hline Total & 100 & 100.0 \\
\hline
\end{tabular}

Source: Survey

\section{Overall Empowerment of Respondents}

Overall empowerment score of a respondent was obtained by summing up the obtained scores for the dimensions of empowerment. On the basis of their empowerment score the respondents were classified into four categories as shown in the Table 8. Data presented in the table showed that the half of the respondents ( 50.0 percent) had medium level of empowerment, while $43 \%$ had low level of empowerment, only $5 \%$ had very low empowerment and $2 \%$ had high level of empowerment. 
INTERNATIONAL JOURNAL OF ACADEMIC RESEARCH IN BUSINESS AND SOCIAL SCIENCES

Vol. 10, No. 16, Youth and Community Wellbeing: Issues, Challenges and Opportunities for Empowerment V2. 2020, E-ISSN: 2222-6990 @ 2020 HRMARS

Table 8. Categorization of women according to their overall empowerment

\begin{tabular}{|c|c|c|c|c|c|c|}
\hline \multirow{2}{*}{$\begin{array}{ll}\text { Category } & \text { of } \\
\text { empowerment }\end{array}$} & \multirow{2}{*}{$\begin{array}{l}\text { Number of } \\
\text { women }\end{array}$} & \multirow{2}{*}{$\begin{array}{l}\text { Percentage of } \\
\text { women }\end{array}$} & \multicolumn{2}{|l|}{ Range } & \multirow[t]{2}{*}{ Mean } & \multirow{2}{*}{$\begin{array}{l}\text { Standard } \\
\text { deviation }\end{array}$} \\
\hline & & & Maximum & Minimum & & \\
\hline Very low & 5 & 5.0 & \multirow{5}{*}{48} & \multirow{5}{*}{15} & \multirow{5}{*}{32.56} & \multirow{5}{*}{7.79} \\
\hline Low & 43 & 43.0 & & & & \\
\hline Medium & 50 & 50.0 & & & & \\
\hline High & 2 & 2.0 & & & & \\
\hline Total & 100 & 100 & & & & \\
\hline
\end{tabular}

Source: Survey

The data indicated that the level of women involved in IGAs who had received microcredit assistance was at medium level of empowerment. This has probably changed since in the past, most of the rural women in Bangladesh was not empowered or have low level of empowerment. Their condition was very miserable; they had little freedom to express their own opinion, to perform their own choice, to go outside from home, to participate in social activities, social functions and to access to asset and resources especially living within the environment of patriarchal society. But the situation is slowly changing. With the efforts of various Government Organizations and Non-Government Organizations, women's situation has improved and their awareness is increasing. Involvement in IGAs and achieving emotional freedom are making the women more empowered. Sarker (2005), in her study found that 41.3 percent women were very low empowered, 48.10 percent were low empowered and only 10.6 percent were medium empowered. Distribution of women according to their overall empowerment score has been visually presented in Figure 1.

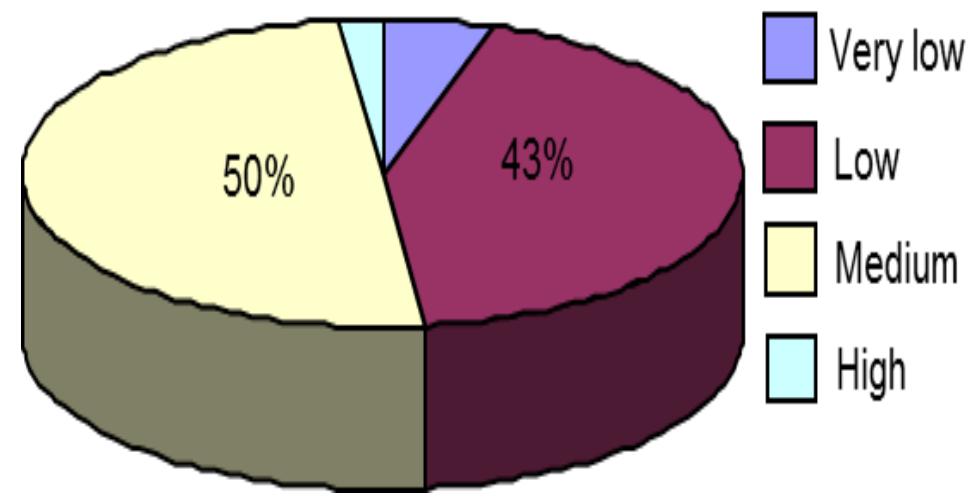

Figure 1. Distribution of rural women according to their empowerment

The low level of empowerment previously was partly contributed by the fact that micro-credit programmes could not reach to a large section of the rural women. The women might have minimal training for income generating activities and did not have enough decision-making power within households to use their loan as well as to control their income. They mostly depend on their husbands or male members for various purposes because micro-credit programmes are unable to eliminate socio-cultural constraints on women's physical access to market (Parvin et al., 2004). In another 
INTERNATIONAL JOURNAL OF ACADEMIC RESEARCH IN BUSINESS AND SOCIAL SCIENCES

Vol. 10, No. 16, Youth and Community Wellbeing: Issues, Challenges and Opportunities for Empowerment V2. 2020, E-ISSN: 2222-6990 @ 2020 HRMARS

study, Parveen and Leonhaeuser (2008) found the economic empowerment of farm women was limited to the low or medium level. Thus, women who are less empowered feel insecure and vulnerable. So, there is a need for enhancing rural women's empowerment to a satisfactory level through undertaking an integrated approach by providing them with more economic opportunities.

\section{Relationship Between the Selected Characteristics of The Women and their Empowerment} Pearson's product Moment Co-efficient of Correlation ( $r$ ) was computed in order to explore the relationship between the selected characteristics of the women and their extent of empowerment through income generating activities. The relationship between the dependent and independent variables is presented in Table 9.

Table 9. Relationship between the selected characteristics of the women and their empowerment.

\begin{tabular}{|c|c|c|c|c|}
\hline \multirow{2}{*}{$\begin{array}{l}\text { Dependent } \\
\text { variable }\end{array}$} & \multirow{2}{*}{ Independent variable } & \multirow[t]{2}{*}{ r-valueswith $98 \mathrm{df}$} & \multicolumn{2}{|c|}{ Tabulated value of ' $r$ ' } \\
\hline & & & 0.05 level & 0.01 level \\
\hline \multirow{11}{*}{$\begin{array}{l}\text { Empowerment } \\
\text { of Women }\end{array}$} & Age & $0.396 * *$ & \multirow{11}{*}{0.197} & \multirow{11}{*}{0.256} \\
\hline & Education & $0.288^{* *}$ & & \\
\hline & Family size & 0.120 & & \\
\hline & Homestead area & 0.195 & & \\
\hline & Annual income & 0.166 & & \\
\hline & Communication exposure & $0.302 * *$ & & \\
\hline & Credit availability & $0.636 * *$ & & \\
\hline & Aspiration & -0.072 & & \\
\hline & Fatalism & -0.052 & & \\
\hline & $\begin{array}{l}\text { Problem confrontation in } \\
\text { participating IGAs }\end{array}$ & 0.165 & & \\
\hline & $\begin{array}{l}\text { Problem confrontation } \\
\text { during loan taking }\end{array}$ & 0.123 & & \\
\hline
\end{tabular}

* Significant at 0.05 level of probability, and ** Significant at 0.01 level of probability

The relationship between age and empowerment through IGAs was significant and followed a positive trend. In patriarchal society, the young women live with her laws and with others. She had to stay under various pressures. She cannot go to many places, cannot do many things if she wished so. A middle-aged woman has more freedom in society. Thus, it could be said that, at least in the present study, age of the women played a significant role in their empowerment.

The relationship between education of the women and their empowerment was significant and it followed a positive trend. The findings indicate that the higher the level of education, the more empowered the women were compared to the lower level of education or illiterate. Education enhances empowerment by increasing access to new knowledge and information which help women to realize their ownership, to challenge injustice and discrimination, to change their outlook. Education enables an individual to become more socialized, to have a wider outlook, to fight against injustice and also to gain better knowledge about every sphere of life both from cultural and 
economic point of view of a society. Malhotraand Schuler (2002) found that there was positive relationship between family education and empowerment of women.

A positive significant relationship was found to exist between the communication media exposure and empowerment. Through communication media exposure of women get necessary knowledge about agriculture, health, sanitation and rural areas that strengthened their earning ability, position in family and society, decision making ability etc. Through communication media exposure she can know how to solve her problems, which enhance the empowerment of women.

The finding indicated that the empowerment of the women increased with the increase of credit availability. This seems to be logical, because high amount of credit leads to high amount of investment and subsequently high profit and subsequently high empowerment. Loan or credit reception empowered women by giving them greater economic value to their families. So it could be concluded that the more loan a women receives, the more empowered the women became. Thus, the finding also supported other studies by Sarker (2005), Hashemi, Schuler\& Riley,1996) and Kabeer (1999) who also found that loan reception is empowering women in Bangladesh.

\section{Conclusion}

In conclusion, it can be said that micro-finance assisted income generating activities are seen to be beneficial for opening economic opportunities of rural women who may not afford to be employed outside their home for socio-cultural reasons. Involvement with BRAC also appears to act as a change agent in reducing women's economic dependence on their husbands and other male kin. Women reported that they now have an independent source of income, they no longer need to rely solely on their husbands for the purchase of personal and household items. Women have also reported an improvement in their relationships with their husbands, primarily because they provide them with capital for investment purposes. As for women's mobility, BRAC involvement has had positive impacts to some extent. Many women never even ventured outside their own locality prior to BRAC involvement, let alone travel to a local market. Traveling to BRAC local offices has given these women opportunities to communicate with the outside world and at the same time has helped them overcome their fear and timidity in dealing with strangers.

In other words, putting financial capital in the hands of rural women may enable them invest in income generating activities and improve food security of their families. Hence, participation of rural women in micro-finance assisted income generating activities was observed to contribute for economical and probably many aspects of empowerment of rural women. However, constraints in accessing loan and loan repayment process should be properly addressed by stakeholders to improve the contribution of micro-finance institutions for achieving sustainable development goals related to rural women in the study area, Sylhet district of Bangladesh as well as also the other developing countries. The major constraints that most of the rural women in the study area faced to participate in micro-finance assisted income generating activities were: lack of awareness, lack of training, lack of collateral, insufficient loan, failure of the business, lack of marketing channels, poor transport facilities, and less cooperation from the family.

In enhancing women's empowerment in a significant way, the concerned agencies, especially the BRAC, should facilitate enough amount of loan for the borrowers with affordable interest rate and long-time loan repayment period is of paramount importance as rural investments require time to generate income or profit along with provision of education and training. This could undoubtedly 
INTERNATIONAL JOURNAL OF ACADEMIC RESEARCH IN BUSINESS AND SOCIAL SCIENCES

Vol. 10, No. 16, Youth and Community Wellbeing: Issues, Challenges and Opportunities for Empowerment V2. 2020, E-ISSN: 2222-6990 @) 2020 HRMARS

act as catalyst to promote socio-economic uplift of rural women in the study villages and rectify long standing gender inequality in Bangladesh.

\section{Recommendations}

Microfinance is recommended as a part of economic growth which may lead to women empowerment and reduce the level of poverty. Strategic recommendations are proposed by the researchers to address the aforementioned major constraints and for further improvement of rural women's empowerment through micro- finance assisted income generating activities with the development of policy that can motivate micro-credit organizations like Grameen Bank, non-local donor agencies and Non-Government Organization (NGO) i.e, BRAC, ASA, PROSIKHA, KARITHAS to extend micro finance activities with less restrictions and encourage the participation of new NGOs to launch microfinance programmes in Bangladesh. There is also a need to look into the sociocultural barriers for women in Bangladesh to participate in economic opportunities by reducing gender discrimination and providing greater accessibility for women to access micro-credit. Women should also be given education and skill acquisition to upgrade their knowledge because this study has indicated that involvement in income generating activities has showed positive impact on economic empowerment of women.

\section{Acknowledgement}

The authors wish to express their sincere gratitude to Organizations for Women in Science For The Developing World (OWSD) and Sida (Swedish International Development Cooperation Agency) for their full cooperation by providing PhD fellowship that enables the study to be conducted.

\section{References}

Akintoye, I. R. (2008). Reducing unemployment through the informal sector: A case study of Nigeria. European Journal of Economics, Finance and Administrative Sciences, 11, pp.97-106.

Albedaiwi, W. (2015). Development, Implementation and Evaluation of a Master's Degree In Healthcare Management and Quality: Recording our Experience. Multilingual Academic Journal of Education and Social Sciences, 3(1), 60-73.

Banu, D., Farashuddin, F., Hossain, A., \& Akter, S. (2001). Empowerment of women: the impact of BRAC's rural development programme. Journal of International Women's Studies, 2 (3): 3053.

Basher, M. A. (2007). Empowerment of microcredit participants and its spillover effects: evidence from the Grameen Bank of Bangladesh. Journal of Developing areas, 40 (2): 173-183.

Batliwala, S. (1994). The Meaning of Women's Empowerment: New Concepts from Action, in: G. Sen; Germain, A., \& Chen, L., C., (eds) Population Policies Reconsidered: Health, Empowerment and Rights. Cambridge: Harvard University Press.

Belwal, R., Tamiru, M., \& Singh, G. (2012). Microfinance and sustained economic improvement: Women small- scale entrepreneurs in Ethiopia. Journal of International Development, 24(S1), pp.S84-S99.

Binswanger, H. P. (2007). Empowering rural people for their own development. Agricultural Economics, 37(s1), pp.13-27. 
Chowdhury, T. A., \& Mukhopadhaya, P. (2014). Are Women Less Efficient in Converting. Microcredit into Functioning's? Evidence from Bangladesh. European Journal of Development Research, 26(5), pp.725-742.

DFID. (2000). Poverty Elimination and the Empowerment of Women: Strategies for Achieving the International Development Targets. London: Department for International Development.

Dejene, Y. (2007). Promoting women's economic empowerment in Africa. In Africa Economic Conference, Ad- dis Ababa (pp. 15-17).

Fletschner, D., \& Kenney, L. (2014). Rural women's access to financial services: credit, savings, and insurance. In Gender in agriculture (pp. 187-208).

Hashemi, S., Schuler, S., \& Riley, I. (1996) Rural Credit Programs and Women's Empowerment in Bangladesh. World Development, 24 (4): 635-653.

Husain, A., M. M., \& Mallick, D. (1998). Poverty Alleviation and Empowerment Conclusion and Policy Implications, Research and Evaluation Division, BRAC Centre, Dhaka. pp. 173-183

Hall, E. (1992). Policies and Programmes of Non- governmental Organization: Their involvement with rural women in Development. Geneva: United Nations.

Jafree, S. R., \& Ahmad, K. (2013). Women Microfinance Users and Their Association with Improvement in Quality of Life: Evidence from Pakistan. Asian Women, 29(4), pp.73105.

Kabeer, N. (1999). The Conditions and Consequences of Choicer Reflections in the Measurement of Women's Empowerment. Discussion. United Nations Research Institute for Social development (UNRISD), Geneva. Paper No. 108,

Kabeer, N. (2002). Resources, Agency, Achievements: Reflections on the Measurement of Women's Empowerment, in: B. Sevefjord and B. Olsson (eds) Discussing Women's Empowerment Theory and Practice. Sweden: Swedish International Development Agency. pp. 17-57,

Mayoux, L. (1998). Research Round-Up women's empowerment and micro-finance programmes: strategies for increasing impact. Development in practice, 8(2), pp.235-241.

Mayoux, L. (2000). Micro-Finance and the Empowerment of Women - A Review of the Key Issues. Geneva: ILO.

Malhotra, A., \& Schuler, S. (2002) Measuring women "s empowerment as a variable in international development. Background Paper Prepared for the World Bank Workshop on Poverty and Gender: New Perspectives

Malhotra, A., Schuler, R. S., \& Boender, C. (2002) Measuring Women's Empowerment as a Variable in International Development. International Centre for Research on Women (ICRW), USA.

Microfinance Gateway. (2008). Available at http://www.microfinancegateway.com/section/faq\#Q1 (accessed on 18 April 2009).

Montgomery, R., Bhattacharya, D., \& Hulme, D. (1996). Credit for The Poor In Bangladesh: The BRAC Rural Development Programme and the Government Thana Resource Development and $\backslash$ Employment Programme' in Hulme D and P Mosely 'Finance against Poverty', Vols. 1 and 2, Routledge, London.

Morduch, J. (1998). Does Microfinance Really Help the Poor: New Evidence from Flagship Programs in Bangladesh, Department of Economics and HIID, Harvard University and Hoover Institution, Stanford University. 
Norwood, C. (2014). Women's Empowerment and Microcredit: A Case Study from Rural Ghana. Journal of International Studies and Development. (4) pp1-22

Ogato, G. S., Boon, E. K., \& Subramani, J. (2009). Gender roles in crop production and management practices: a case study of three rural communities in Ambo district, Ethiopia. Journal of Human Ecology, 27(1), pp.1- 20.

Omar, M. Z., Noor, C. S. M., \& Dahalan, N. (2012). Financing an income generating activity among the poor rural households: the case of the Amanah Ikhtiar Malaysia. International Journal of Social Sciences, 1(1), pp.107-129.

Parveen, S., \& Leonhaeuser, I. U. (2008). Factors Affecting the Extent of Economic Empowerment of Women in Farm Households: Experiences from Rural Bangladesh. International Journal of Human Ecology, 9 (December): 117-126.

Parvin, G. A., Ahsan, S. M. R., \& Chowdhury, M. R. (2004). Women Empowerment Performance of Income Generating Activities Supported by Rural Women Employment Creation Project (RWECP): A Case Study in Dumuria Thana, Bangladesh. The Journalof Geo-Environment,. 4: 47-62.

Pitt, M. M., Khandker, S. R., and Cartwright, J. (2003) Does Micro-Credit Empower Women? Evidence from Bangladesh. The World Bank Policy Research. Working Paper No. 2998, New York.

Sukontamarn, P. (2007) Micro-credit, fertility decisions and women's empowerment in Bangladesh. School of Economics, the University of Adelaide, Australia.

Sarker, T. (2005). Empowerment of women Beneficiaries through Self-help Groups in Bangladesh. $M$. S. (Ag.Ext.Edu.) Thesis, Department. Of Agricultural Extension Education, Bangladesh Agricultural University, Mymensingh. Bangladesh.

Webb, P., Coates, J., \& Houser, R. (2002). Does micro-credit meet the needs of all poor women? Constraints to participation among destitute women in Bangladesh. The Gerald J. and Dorothy R. Friedman School of Nutrition Science and Policy, USA.

Sudan, F. K. (2007). Livelihood Diversification and Women Empowerment through Self-Help Micro Credit Programme: Evidence from Jammu and Kashmir. Indus Journal of Management \& Social Sciences, 1(2), pp.90-106.

Wekwete, N. N. (2014)). Gender and Economic Empowerment in Africa: Evidence and Policy. Journal of African Economies, 23(1), pp.i87-i127. 